Educational Research for Social Change (ERSC)

Volume 10 No. 2 September 2021

pp. 47-62

ersc.nmmu.ac.za

ISSN: 2221-4070

\title{
Raising Awareness of Agency to Address Climate Change: The Do One Thing (DOT) Strategy ${ }^{1}$
}

\author{
Irene Muller \\ ORCID No: 0000-0001-9018-5771 iD \\ COMBER, Faculty of Education \\ North-West University \\ 12765074@nwu.ac.za \\ Lesley Wood \\ ORCID No: 0000-0002-9139-1507 \\ COMBER, Faculty of Education \\ North-West University, lesley.wood@nwu.ac.za
}

\begin{abstract}
The United Nations Children's Fund 2008 report, Our Climate, Our Children, Our Responsibility, warned that children will suffer most from the effects of climate change. Environmental education is one way to prepare children to cope and enable them to educate their families and friends about the need to act now to minimise the danger climate change poses. This article reports on findings from a participatory action research project aimed at integrating education for sustainable development into the Grade 7 curriculum, with a specific focus on climate change. Critical participatory action research has a transformative intent, engaging participants in learning to cultivate a sense of purpose and increase their capacity to solve local problems. Learner responses to qualitative questionnaires and recorded discussions related to the Do One Thing (DOT) strategy were used to determine learning about climate change and enable both learners and community members to identify action for change. Thematic coding was used to evaluate the effectiveness of the DOT strategy in increasing awareness of agency and resultant learning. The findings indicate that not only did the learners gain knowledge about the causes and consequences of climate change but the potential of the learners and community members to identify possible actions for change was increased as well. We provide suggestions as to how teachers can use the DOT strategy as part of an action research approach to integrating environmental education for sustainable development in order to raise awareness of local environmental threats and encourage learners and their families to behave in a more environmentally friendly way. The explanation of the research process offered in this article also highlights how participatory learning activities can help engage learners as active agents in their own learning.
\end{abstract}

Keywords: climate change, collaboration, experiential learning, participatory action research, project-based learning

\footnotetext{
${ }^{1}$ Ethical clearance number: NWU-00483-17-A2
} 
Copyright: (c) 2021 Muller and Wood

This is an open access article distributed under the terms of the Creative Commons Attribution NonCommercial License, which permits unrestricted non-commercial use, distribution, and reproduction in any medium, provided the original author and source are credited.

Please reference as: Muller, I. and Wood, L. (2021). Raising Awareness of Agency to Address Climate Change: The Do One Thing (DOT) Strategy. Educational Research for Social Change, 10 (2), 47-62. http://dx.doi.org/10.17159/2221-4070/2021/v10i2a4

\section{Introduction}

The 2008 United Nations Children's Fund (UNICEF) report, Our Climate, Our Children, Our Responsibility, indicated that children are among those most exposed to the effects of climate change (Bangay \& Blum, 2010). In addition, the United Nations Educational, Scientific and Cultural Organization (UNESCO, 2012a) supported the widely held view that formal education, public awareness, and training are all critical elements in community response to the challenges of climate change. The current global trend in climate change education calls for the integration thereof into broader approaches, and recommends focusing education about climate change on a specific age group such as the senior phase learners in primary schools (UNESCO, 2012a). The integration process calls for more complex links in the provision of, and access to, the development of climate change educational initiatives (King et al., 2007), including inter- or transdisciplinary approaches and opportunities to share experiences regarding climate change. This article explains the usefulness of a project-based learning strategy, Do One Thing (DOT), to enable learners to research the consequences of climate change in their communities and use this knowledge to engage with the wider community to find ways to combat its deleterious effects.

A 2011 report issued by UNICEF in South Africa, Exploring the Impact of Climate Change on Children in South Africa, indicated that climate change negatively influences children's emotional and social status as well as their health, nutrition, education, and developmental pathways. The report also confirmed that children are willing and able to confront issues related to climate change that have an impact upon their own well-being and that of their communities. Effective means of enabling children to address issues of climate change include education, mitigation, and adaptation -all of which engage them actively and provide them with the necessary knowledge, skills, and confidence to address these issues (UNICEF, 2011). To begin to implement the recommendations of this report, strategies such as DOT, as part of a wider education for sustainable development (ESD) agenda, enable learners to act as citizen scientists (Conrad \& Hilchey, 2011) to identify climate change indicators in their communities, analyse and interpret data, and identify possible actions to lessen climate change. By communicating their understanding of climate change, and how to address it-both locally and globally-they can be powerful influencers for action to mitigate the effects of climate change in their communities.

Along with colleagues, we, as researchers, are currently part of an international climate change project to empower teachers to develop learners as citizen scientists who can advocate for environmentally friendly behaviour. The focus of the findings in this article is linked to research in one of the project sites in Gauteng, South Africa. In the third cycle of the project, teachers used a project-based learning strategy, DOT, to enable learners to identify the causes and consequences of climate change in their communities and to consult with their families and other community members to decide on one specific action that each could take to mitigate these consequences. We first present the background to the project, and the underlying theoretical framework, before explaining the methodology used in the third cycle. The findings are then discussed and their significance for future teaching of ESD in primary schools explained. The main research question that guided the third cycle of the project was: 
"How can Grade 7 teachers use the DOT strategy to raise awareness about, and encourage action to mitigate, climate change?"

\section{Integrating ESD Into the Curriculum: Some Pedagogical and Theoretical Perspectives}

Project-based learning (PBL) is one approach to integrating ESD into the curriculum. This type of learning is centred on learning in the real world and allows for the active participation of learners to obtain both subject knowledge and skills (Killen, 2010; South African Institute for Distance Education, 2012). As an approach, PBL is grounded in experiential learning theory (Kolb \& Kolb, 2005). The outcomes of both PBL and experiential learning theory follow the cyclical process innate to action research: identification of the problem, determining how to address it, taking action, reflecting on the outcomes, and disseminating the knowledge to others (Efstratia, 2014). However, PBL presents some challenges such as difficulty in determining the learning of the individual, relying, as it does, on collaboration. The impact of the affective domain on participant experience is another intricate concept to determine (Brundiers et al., 2010). However, the benefits of PBL outweigh these negatives.

McCright (2012) reported that learners who are exposed to experiential learning and PBL are actively engaged in and learn from collaboration and sharing ideas with their peers. Learners are encouraged to maintain their curiosity and apply their knowledge in real-life situations (McCright, 2012). They benefit from participation in experiential learning and PBL linked to climate change education because these promote deeper learning that fosters comprehension, cross-referencing, and independent thinking relevant to ecological and sustainability issues. Deeper learning also encourages internal motivation (Otto \& Pensini, 2017). Boylan (2008) pointed out that learners' understanding of the concept of climate change is not often addressed in research. This research study therefore responds to the need to deepen our understanding of how young learners and their adult family members interpret and respond to the topic of climate change.

Schweizer et al. (2013) indicated that the relevancy of climate change projects is increased if they are situated in appropriate cultural values and beliefs meaningful to the participants, and actionorientated. Anchoring this project in a specific community of interest, a primary school in Vanderbijlpark, allowed for the features posited by Schweizer et al. (2013) to be incorporated. Brownlee et al. (2013) used the concept of place attachment or place bonding to indicate the cognitive and affective bonds people build with places of interest and specify that participants' beliefs, values, and attitudes determine their understanding of climate change. The behavioural change of participants thus depends upon psychological, human-evolutionary, and social-ecological circumstances (Brownlee et al., 2013). Otto and Pensini (2017) reported that both environmental knowledge and connectedness to nature are necessary components to nurture positive ecological behaviour; to them, motivation is a key factor to enhance responsible behaviour towards nature. Brownlee et al. (2013) were of the same opinion, and indicated that possible psychological processes that can hinder climate change education include the following: (i) an ability to ignore relevant evidence, (ii) loss aversion, which refers to the trends in communities to maintain the status quo and to avoid short-term losses despite the potential of long-term gain, and (iii) the inefficacy of individual action-where individuals believe that changing their behaviour will not make a difference to a global problem such as climate change.

Human-evolutionary processes include the interaction of humans with the natural environment and comprise two dimensions. The temporal dimension in the human-evolutionary process involves the desire to receive immediate rewards instead of waiting for future gains, for example, loss aversion. The spatial dimension indicates that most humans react in their immediate household and personal space. Climate change as a phenomenon demands action on a wider scale or spatial dimension, but 
change should also start at a local and individual level. Furthermore, research has shown that knowledge about climate change is best converted with small-scale resources known to the participants (Brownlee et al., 2013).

Social-ecological processes in communities include human-environment and human-human interactions. Examples of these processes in communities are the consumption of fossil fuels (e.g., the heating of food, watching sport, and driving to parks and natural environments) and the governance of natural resources. The belief in science and trust in scientific evidence rely on the ability of community members to interpret scientific data and relate the data to their situation (Brownlee et al., 2013). In this project, we aimed to develop learners as citizen scientists to be able to counteract the negative effects of these hindrances and encourage the adoption of environmentally friendly behaviour. Next, we detail the background of the larger action research project in which the DOT was used.

\section{Background of the Environmental Education for Sustainable Development Climate Change Project}

In 2019, an opportunity arose for the North-West University Environmental Education for Sustainable Development Climate Change project to join a global participatory action research (PAR) project to implement initiatives on climate change education by developing primary school learners as citizen scientists (De Sousa, 2018). This project allowed participants to share initiatives with their counterparts in other countries (South Africa, the United States of America, Germany, the Philippines, and Norway). This inter-university, inter-country participation aimed to align the learning and development of climate change educational opportunities among primary schools in diverse countries using a PBL approach (Tyler-Miller \& Spoolman, 2019).

Although the South African leg of the project was implemented in three primary schools situated in disadvantaged communities, we only report on the findings from the site in which the first author was the lead researcher. The primary school is in a suburb of the town of Vanderbijlpark, Gauteng. The school has about 900 learners and 40 teachers, a better teacher-learner ratio than most primary schools in the country. The school is in a residential area with homes, small businesses, open public parks, and sports fields. The local community is exposed to a high level of pollution (air, water, and soil) due to the activities of large-scale corporations such as SASOL (the organic carbon-chemical industry in nearby Sasolburg) and ArchelorMittal (an iron refinery situated in Vanderbijlpark). Due to technological advances and the dwindling demand for such products, the community has suffered a lot of job losses and, therefore, the unemployment rate is very high. Coal mines in the area and the power plant run by ESKOM, the national power utility, also contribute significant air and water pollution. Vanderbijlpark is within an hour's drive from Johannesburg, the biggest city in South Africa. Many of the parents bring their children to school and then travel on to Johannesburg for their working day. Private and public transport thus adds to the high level of air pollution.

The first cycle of the project entailed meeting with teachers and community representatives to identify and discuss the environmental issues they were facing in this specific area. The meetings provided rich contextual detail on a range of challenges experienced by residents and teachers who were troubled by the degradation of the natural environment, a lack of waste management or removal of waste, water and air pollution, and sewage leaks, which they said had a severe impact on the health and wellbeing of the community and were threatening food security. The group agreed that climate change education was needed to enable change in community attitudes and behaviour. They captured these ideas in a logo to indicate their vision of, and commitment to, communal environmental concerns (see Figure 1). This completed the first cycle of the project. 


\section{Figure 1}

Logo for the Environmental Education for Sustainable Development Climate Change Initiative

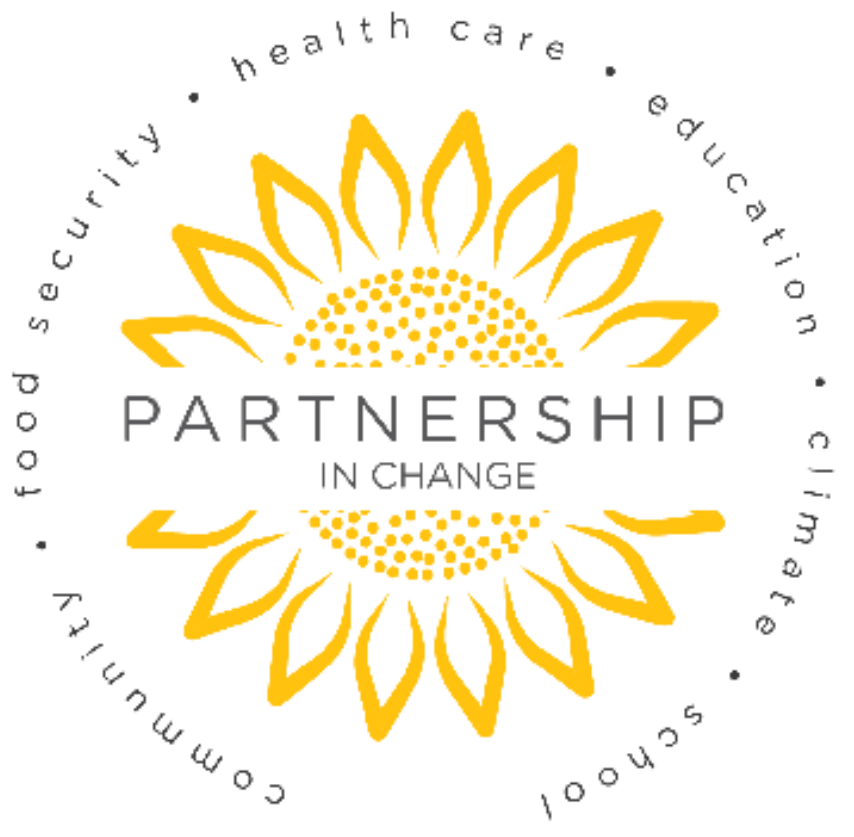

The second cycle of the project was aimed at building the capacity of Grade 7 teachers to integrate ESD into their respective subjects. Grade 7 was targeted in response to the recommendation of UNESCO (2012a) to target senior primary school learners. Other colleagues in the larger project helped to facilitate a workshop where teachers learnt strategies to enable them to infuse climate change into various subjects, and appreciate the real-life relevance of climate change by linking subject knowledge to possible sound environmental action (see De Sousa, 2018). Various teaching tools, such as the use of graphical information and case studies from newspapers and international media, were used to explore the topic. Table 1 summarises the national Curriculum Assessment Policy Statement (CAPS) documents for Grade 7 (Department of Basic Education, 2011) that refer to topics that link well with climate change in subjects that grade. The table displays the CAPS subjects and topics and their relevance to climate change initiatives. 
Table 1

Possibilities for the Implementation of Climate Change Content in Grade 7 CAPS

\begin{tabular}{|c|c|c|c|}
\hline Subject & Topic in CAPS & $\begin{array}{c}\text { Connection to climate } \\
\text { change }\end{array}$ & $\begin{array}{c}\text { Classroom initiative } \\
\text { proposed }\end{array}$ \\
\hline Life skills & $\begin{array}{l}\text { Health and social and } \\
\text { environmental } \\
\text { responsibility }\end{array}$ & $\begin{array}{l}\text { Environmental health- } \\
\text { community and } \\
\text { individual projects and } \\
\text { strategies to prevent and } \\
\text { deal with environmental } \\
\text { problems }\end{array}$ & $\begin{array}{l}\text { Design of an action plan } \\
\text { to address } \\
\text { environmental health } \\
\text { problems and formulate } \\
\text { sound environmental } \\
\text { choices and actions }\end{array}$ \\
\hline Social science & $\begin{array}{l}\text { Population growth and } \\
\text { change }\end{array}$ & $\begin{array}{l}\text { Responses to growing } \\
\text { populations }\end{array}$ & $\begin{array}{l}\text { Identify reasons for this } \\
\text { and propose action to } \\
\text { meet the demands of } \\
\text { the growing population } \\
\text { on the local } \\
\text { environment }\end{array}$ \\
\hline $\begin{array}{l}\text { Natural science and } \\
\text { technology }\end{array}$ & Energy and change & $\begin{array}{l}\text { Renewable and non- } \\
\text { renewable forms of } \\
\text { energy; energy in } \\
\text { biological systems; heat } \\
\text { and heat transfer; the } \\
\text { solar heating system and } \\
\text { ways to keep objects } \\
\text { cold; useful and wasted } \\
\text { energy; the } \\
\text { interpretation of energy } \\
\text { in the national grid }\end{array}$ & $\begin{array}{l}\text { Designing and building } \\
\text { systems using relevant } \\
\text { materials such as } \\
\text { renewable energy to } \\
\text { transfer heat or prevent } \\
\text { the transfer of heat; } \\
\text { investigating electrical } \\
\text { apparatus at home (e.g., } \\
\text { which use the most } \\
\text { energy?); suggesting, } \\
\text { writing, and discussing } \\
\text { ways to preserve heat or } \\
\text { reduce energy } \\
\text { consumption; } \\
\text { investigating possible } \\
\text { careers in the energy } \\
\text { field }\end{array}$ \\
\hline
\end{tabular}

\section{The DOT Strategy}

Across countries, the decision was made to use the DOT strategy in the third cycle as one way of integrating ESD into the curriculum. The name indicates that small changes to how people interact with the environment can make a big difference given that individual actions have a cumulative effect. This idea was taken from a global project, championed in South Africa by Braam Malherbe, an environmental activist. He identified the four vital areas of concern for climate change in this country, namely, water, waste, conservation, and energy (Malherbe, 2020). The DOT project supports the infusion of climate change knowledge into a range of school subjects such as life skills, social science, and natural science and technology. Teachers who attended the workshops linked topics in their respective subjects to climate change. Learners were tasked to explore subject content and use the information gleaned to guide action on climate change in their communities. We decided to use the DOT strategy because it raises awareness of local environmental threats and also initiates ideas for action for change. The learners were requested to discuss what they had learnt in the classroom about climate change with a responsible adult at home (a family member or family friend) and ask them to indicate on a paper "leaf" (provided by the teacher) one thing they could think of to lessen the harmful effects of climate change in their community. The learners were to do the same on another leaf. The next day, the learners came to school with the two leaves that indicated their ideas on the action they could take to combat climate change. They were asked to post the leaves on a "DOT tree" (see Figures 2 and 3 ). The strategy also doubled as a source of data. 
Figure 2

Learners Posting Leaves on the DOT Tree

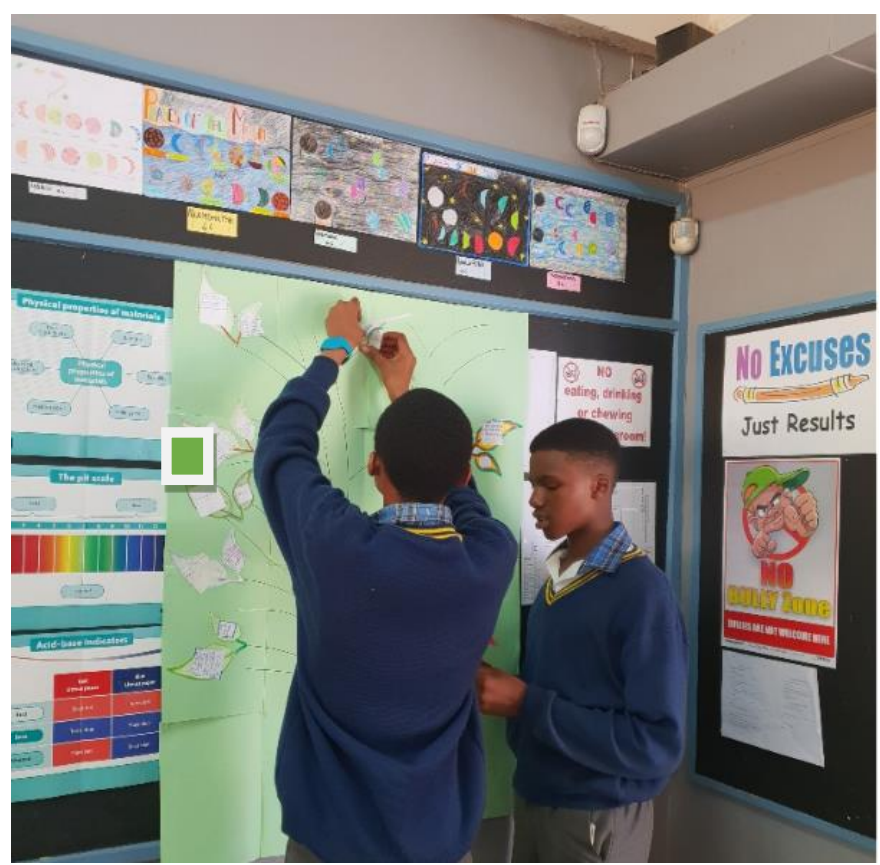

Figure 3

Examples of Pledges Displayed on the DOT Tree

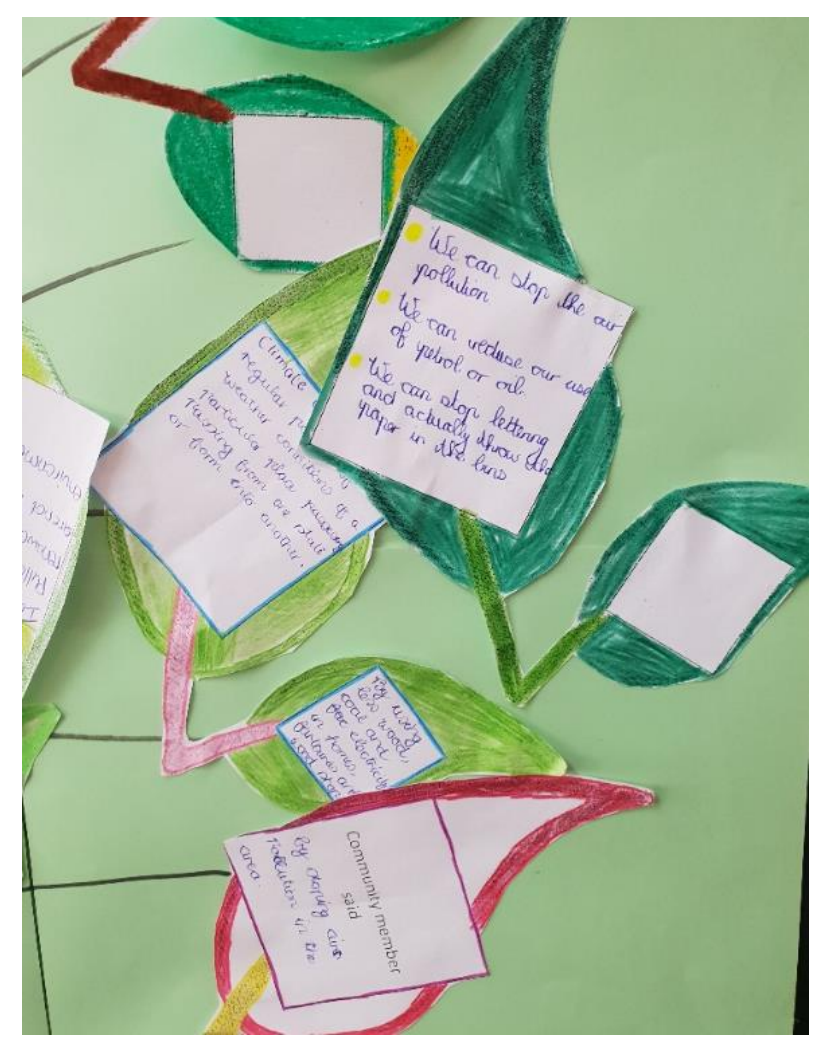

\section{Research Methodology for the Third Cycle}

Working from a social-constructivist paradigm (see Grauer, 2012), we positioned ourselves as participants in the PAR project group. The contribution of the first author to the project was her expertise in ESD and how to integrate it into the school curriculum; the second author shared her 
expertise in the PAR process. To gain the trust of the other participants, including community members, teachers, and learners, the larger project demanded an extended investment of time (2017 and onwards). Fals-Borda (2006) explained that PAR is based on "an examination of local social, cultural, historical, and environmental roots in order to explain, describe, systematize, and transform contexts and existing conditions" (as quoted in Santos, 2013, p. 498). As participants, we converged our different, but equally valid, knowledges (see Fals-Borda \& Mora-Osejo, 2003) to come to a better understanding of the climate change issues facing the community and how to address these. The project was conducted in cycles of action and reflection, as befits PAR, and we used the DOT strategy in Cycle 3, where learners, as citizen scientists, shared their learning about climate change with community members and committed to actions to minimise the negative effects thereof (see Figure 4).

\section{Figure 4}

\section{The Cycles of the Climate Change Project}

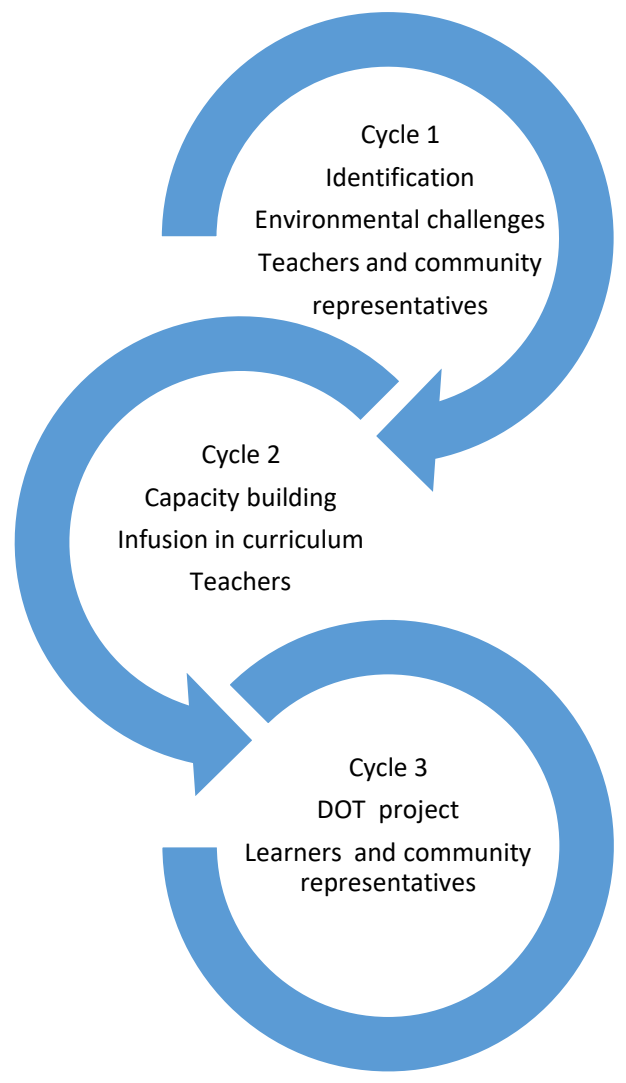

According to Minkler (2000), PAR relies on a bottom-up approach with a focus on social learning to promote change in communities. Furthermore, PAR develops the self-efficacy of participants and increases their capacity to solve local problems (Minkler, 2000). Consequently, the climate change project accommodated three basic aspects of PAR: (i) active participation of teachers and learners, (ii) the creation and dissemination of knowledge by learners through sharing experiences in the project locally with their families (and later, globally via Skype interviews with their peers in other countries), and (iii) the development of learners as researchers or citizen scientists who learnt about climate change, identified specific local consequences, and advocated for behaviour change to mitigate the impact of climate change. 
The research methods used in Cycle 3 are explained next. The school was chosen because of the commitment of the management to promote environmental education (e.g., by planting trees and enforcing strict policies about littering). The school also runs an ongoing recycling project in which learners place glass and plastic in separate bins to be sold to a local recycling business to raise school funds. The principal was keen for her school to be involved in this project. She formally invited the Grade 7 subject teachers in natural science and technology, social science, and life skills to participate. Two subject teachers in natural science and technology and social science volunteered to implement the various climate change content and activities they had learnt in the workshop with 49 Grade 7 learners in the classroom. The DOT strategy required learners to participate as producers of knowledge about climate change issues in their communities by providing their ideas, and those of their family and friends, on how to take action to mitigate the effects of climate change. The DOT strategy was rounded off with a Skype conversation with learners of the same age group at a school in Louisville, United States of America who had also done it in their Grade 7 class. The Skype conversation was regarded as a review opportunity for the learners to share experiences with peers and communicate their findings of the DOT activity to others.

The data set consisted of (i) pledges of both the community and learners captured on the DOT leaves and (ii) learners' responses to open-ended questions: (a) Explain your understanding of the concept climate change, (b) Discuss your learning from the Skype meeting with the USA learners, and (c) Indicate three more things you can do to lessen the impact of climate change. We compared the answers to (a) with the transcribed discussion with community members in Cycle 1. Thematic coding of qualitative data (Tesch, 1990, as explained in Creswell, 2009) provided insight into the dynamics of teaching climate change and the influence of the DOT project on the learning of Grade 7 learners. Trustworthiness, an indication of the authentic experience of the climate change project (see Creswell, 2009), was enhanced by adhering to the following requirements: the use of multiple data sets, and verifying the findings and controlling for bias by recoding the data by the two authors of this paper. This was done independently, before coming to a consensus through discussion. The Environmental Education for Sustainable Development Climate Change project was approved by the Education, Management and Economic Sciences, Law, Theology, Engineering, and Natural Sciences Research Ethics Committee (EMELTEN REC) of the North-West University, indicating that it complied with strict ethical guidelines concerning voluntary participation, respect for the participants' rights, and fairness in selection and treatment.

\section{Discussion of the Findings}

In response to the research question, three themes emerged from the data analysis. We were especially interested in finding out how the DOT strategy enhanced the knowledge and influenced the attitudes, and perhaps even behavioural intentions, of both the learners and the community members.

\section{Theme 1: Increased Awareness of Climate Change Impact}

Climate change education "helps learners to understand the causes and consequences of climate change, and fosters the acquisition of skills and dispositions that individuals and communities need to achieve low-carbon and climate-resilient development. It also enhances the education system's preparedness for and responses to climate change, both in terms of mitigation and adaptation" (UNESCO, 2012b, p. 2). However, the multidimensional nature of climate change as a social, environmental, and political issue, as well as a scientific phenomenon, makes it a difficult concept for participants to understand (Trott, 2019). The DOT strategy aims at simplifying the concept by requiring learners to explain the implications of climate change in simple language to their adult family members, and to exact a commitment to adopt one behaviour to help mitigate these implications. Studies have shown that informal environmental education has a more direct impact on awareness, 
attitudes, and motivation to behave in an environmentally friendly way than does formal education (Grosseck et al., 2019). The DOT project, however, enabled formal education to influence the community response to climate change.

The diverse responses of both adult and learner participants indicated that they had not quite grasped the multidimensional nature of climate change-focusing only on the link to changing weather patterns rather than on the extensive social and economic effects it produces. According to Adult 4, "climate change occurs when changes in the earth's climate system result in new weather patterns that last for at least a few decades." Learner 5 said, "a long period of time [passes as] . . the climate changes [occur]. As the climate warms it changes the nature of global rainfall, evaporation, snow, stem [steam?] flow and other factors that affect water supply and quality."

Moreover, the participants understood that climate change resulted from the actions of humans. The ability of participants to link climate change to specific environmental indicators, such as ozone depletion, air pollution, and the loss of natural life, suggests an enhanced awareness of climate change effects from a scientific perspective. According to Adult 6, "due to human emission of greenhouse gases, atmospheric air pollution has increased ... due to the release of methane and nitrous oxide since the industrial revolution." Learner 10 pointed out that "the weather changes ... maybe because of the litter, chemicals, and fumes." Adult 8 said, "climate change affects all kinds of animals, plants and humans and can place a negative input on our environment."

This superficial and generalised understanding of climate change impacts points to the need to relate ESD to the lived experiences of specific communities in order to make it more meaningful (Schweizer et al., 2013). Otto and Pensini (2017) found that connectedness to nature, where learners can investigate the local effects of climate change, is more likely to influence behavioural change in learners. In addition, investigating local issues has an emotional dimension that also has a positive relationship with behaviour (Otto \& Pensini, 2017). The teachers had continued to teach from a theoretical perspective instead of using local examples to explain the impact of climate change. This is something we will have to focus on in our future interaction with the teachers. The second theme expands on the commitment of the participants to take action to mitigate climate change.

\section{Theme 2: Increased Commitment to Adopt Environmentally Friendly Behaviour}

Responsible action, displayed as commitment to mitigating climate change, can be regarded as activities that promote a healthier natural environment. Such activities can include the reuse and recycling of material to reduce pollution, the planting of trees, walking more and driving less, and using water as a natural resource, responsibly. As stated, the personal connection of people to climate change is enhanced by their understanding of its local impacts (Zanocco et al., 2019). Adult and learner responses to motivate the theme are discussed separately because the learners, who had been taught about climate change in different subjects, responded, in comparison to the adult participants, with more diverse answers.

Most of the adults' comments on the DOT leaves were linked to the mitigation of littering, thereby reducing the pollution of natural resources, and saving natural resources. Littering is one of the most problematic environmental problems in the low-income areas in South Africa, where abandoned plastic bags are often referred to as "township daisies" because they are strewn over the ground like flowers. Townships also tend to be devoid of trees because poverty forces people to use the wood as fuel for cooking and warmth. This highlights the problems that poverty poses for environmental health. Even if people are environmentally aware, and would like to live in a way that conserves natural resources, they often do not have the freedom of choice to do so. 
The adult participants indicated that they would "stop people from littering" (Adult 15) and take action themselves - "we can stop the way we litter and stop all pollution around the world, we can put rubbish in bins" (Adult 16). The adults were also concerned about natural resources and were aware of actions to minify the use of water by indicating that people should "use less water" (Adult 2) and there should be "no dripping taps" (Adult 8). Furthermore, people should "not cut trees" (Adult 10).

The learners, who had been taught about climate change in different subjects, responded with more scientifically based ideas compared to the adult participants. They had learnt in social science about how the growing population affected climate change, so they pledged to "use less fossil fuel by investing more in renewable energy, for example solar power, wind and water generated power" (Learner 24) and "consume less, waste less" (Learner 8). Regarding the theme of energy and change in natural science and technology, the learners suggested they should "use less wood" (Learner 1), "create litter committees; spread awareness of what factories are doing by damaging the environment; re-using, reducing and recycling" (Learner 36), and "use electric cars" (Learner 27). The assumption can be made that exposure to climate change in the curriculum has enabled the learners to propose strategies to mitigate climate change on a wider scale. Although it is unlikely that the learners could influence change in the way local factories produce their goods or afford to buy any car, let alone an electric one, their increased awareness of the dangers posed by this form of pollution may in time influence them to take action where they can make a difference.

The response of both groups of participants can be linked to their immediate environment and context, where littering and pollution are the most visible effects of the role of humans in environmental degradation. Although they are not able to "stop all pollution around the world," the participants were inspired to pledge to put their litter in bins instead of discarding it in public spaces. Such pledges can help to overcome the psychological barrier of the inefficacy of individual action (Brownlee et al., 2013). The learners' responses indicate that theory learnt in the classroom relates with real-life contexts and can inspire positive activity towards the natural environment by youth (see Curtin \& Fossey, 2007). They also pledged to make changes that were in their control, such as "we must keep the environment clean" (Learner 25), "stop people from littering" (Learner 7), and "plant more trees" (Learner 8).

The responses of the learners addressed the three prime foci of DOT projects in South Africa, namely, waste, conservation, and energy (see Malherbe, 2020). The display of increased knowledge and commitment to responsible action to lessen the impact of climate change can be linked to the active participation of the learners in the project, as suggested by McCright (2012). The responsible actions indicated by the learners and adults were thus an application of knowledge to real-life situations (Boylan, 2008) as recommended by UNESCO (2019), which suggested that environmental education not only provides learners with knowledge and skills, such as critical self-reflection, but also encourages them to undertake transformative actions for sustainability. The DOT project can thus be seen as having increased the participants' sense of action competence, which may ultimately facilitate social change. The learners' willingness and ability to participate successfully in a discussion regarding climate change are indicated by the third theme, which mostly emerged from their reflections on their experience of discussing the DOT strategy with their peers in the United States of America.

\section{Theme 3: An Improved Ability to Communicate About Climate Change}

Learners acted as citizen scientists in the DOT project. "Citizen scientist" is a term to convey the involvement of lay people in collecting and analysing data in scientific projects-although they are not usually the project planners (Grauer, 2012). We adopted this approach because climate change learning is supported when learners are actively engaged in carrying out projects (see Monroe et al., 2017). The DOT project also served as a platform to expand agency and informed action to mitigate climate change by involving learners in written and verbal communication about this important issue. 
The Skype discussions with peers at a school in Louisville, Kentucky, in America provided the learners with an opportunity to showcase their knowledge on climate change as capable, informed citizens. It also helped to improve their ability to discuss the global issue of climate change, linking it to a positive emotional experience. According to research conducted by Grund and Brock (2020), there is a strong positive correlation between affirmative emotional links to climate change and sustainable behavioural change. The learners were requested to reflect on their experience of discussing the DOT project and climate change issues with children their age from a different part of the world, and to indicate what they had learnt from the experience.

The learners were excited about the interview because it was a novel experience to communicate via Skype (they did not have access to computers at home and had only very limited access at school) and also because they had never conversed with children from another country. As Learner 4 said, "I only see American children in movies." They also expected that the American children would know more than them- "I expected a lot of answers from the USA learners" (Learner 2). The affective domain and emotional gain of PBL, as in the DOT project, are often neglected (Brownlee et al., 2013; Brundiers et al., 2010). Sustainable behaviour change in terms of ESD is positively related to a conducive affective environment (Grund \& Brock, 2020), and so we were glad the learners experienced the interaction as positive- "exited, happy and glad" (Learner 1 ) and "felt appreciated to get a chance to speak to a person living on another part of the world" (Learner 10). Even those who were initially nervous and anxious seemed to relax once the meeting started: "I got more comfortable as the meeting went on" (Learner 5).

They learnt that, even though their living conditions were very different (e.g., the American learners did not live in the extreme poverty experienced by the South African learners), the impact of climate change was equally negative on both sides of the world. The South African learners spoke of the water and air pollution they faced daily. They shared their concerns about the spillage of sewage in the nearby Vaal River, which made it unsafe for swimming and caused terrible odours in the community. The American teenagers shared that they too, were concerned about air pollution due to the use of fossil fuels. They also discussed what their respective schools were doing to mitigate climate change.

The Skype interview enabled the learners to learn from one another - "they told us about the causes of climate change and we tell them our good and bad effects of climate change" (Learner 22). The learners indicated that the DOT project allowed them opportunity to think about the long-term effects of climate change, and how their individual and collective actions as a community could help protect the environment. After the project, they understood more about the urgency of "saving our world" (Learner 20).

Learners in their teenage years are still forming their value system and worldview. Self-transcendent values, such as concern for the welfare of others, are associated with positive engagement with climate change while self-enhancing values linked to wealth, status, and power, are generally not (Corner et al., 2015). The reflections of the learners on the DOT project were more indicative of self-transcendent values, such as mutual concern for their shared environment, which hopefully would encourage them to sustain their interest in climate change issues.

Climate change initiatives compete for the attention of young people against social media, technology, and teenage concerns and worries. All these require from young people a more immediate response than the gradual process of climate change measured over decades (Corner et al., 2015). Climate change education can evoke feelings of anxiety, stress, and despair about a future that cannot be easily predicted or controlled (Grund \& Brock, 2020). Some learners were emotionally affected by the discussions arising from the DOT project. For example, Learner 1 wrote: "A bad experience. We talked 
about what affects our world and what could we do to reduce climate change." Learner 17 called it a "bad experience, because animals die because of us." Although such negative emotions can inhibit action by inducing feelings of powerlessness that are a hindrance to self-efficacy, pro-environmental engagement, and behaviour change (Corner et al., 2015), it is important that teachers learn to contain these feelings in learners instead of using them as an excuse to avoid discussing climate change (Pace, 2019). Verlie (2019) suggested that teachers need to cultivate "openness to emotional challenges, a capacity to endure, live through, welcome and encourage changes and to guide others in their efforts" (p. 760). Given the existential dilemma posed by climate change, it is normal that young people may experience fear, worry, and anxiety when discussing the potential threat to future life (Grund \& Brock, 2020). This was not something we touched on in our workshop with teachers, but it is an area we need to explore in future cycles.

Interacting with peers across the world helped the learners learn about themselves and their world while, at the same time, learning about the effects of climate change in another country. Moreover, the learners indicated that collaboration with peers, via Skype interviews, motivated them to learn more about the effects of climate change in their community. The additional information shared, despite diverse cultures and living conditions, developed their understanding of themselves as citizens whose actions are relevant to the health of the environment-which will, hopefully, influence their future behaviour in this regard.

Sen's (2010) capability theory posits that (sustainable) development is hampered when people do not have the freedom to choose behaviours that they would like to enact (capabilities) and, instead, have to act in a way that is harmful to the environment (e.g., cutting down trees for fuel) because their economic status does not allow them the luxury of purchasing alternative options. So, although environmental education informs people about what behaviours they should be adopting, real-life circumstances constrain their capability for making healthy choices. Consequently, the participants in the research study decided to take action to survive despite the degradation of the environment. Our research therefore agrees with the view of Otto and Ziegler (2010), who pointed out that formal education tends to stress capabilities (making sound choices) over functioning (actions people have no choice but to do). The DOT strategy thus helps to close this theory-practice gap by encouraging the adoption of behaviour that is feasible and sustainable, even in contexts of poverty. The DOT assignment increased awareness of climate change by advocating a pragmatic course of action that learners and their families could take to address climate change on an individual level (Trott, 2019). It also inspired interest and engagement (Trott, 2019) by requiring learners to act as educators and advocates of more environmentally responsible behaviour.

\section{Conclusion}

This research was grounded in the moral obligation, as indicated by UNESCO (2012a) and UNICEF (2011), to include children as key stakeholders in the mitigation of climate change. The use of a participatory teaching approach and the DOT strategy, rather than didactic forms of teaching, prepared the participating learners for future realities and emphasised their role as partners in the mitigation of climate change. The Grade 7 learners were able to act as agents of change in their school and local community by constructively engaging in this as citizen scientists through learning about climate change in their various subjects, sharing this knowledge with adults in their community (parents, family friends, etc.), asking them to make a commitment to mitigation of climate change, and making similar commitments themselves. As future adults, young people are potentially in the most suitable position to lead long-term societal responses to climate change. They have the most to gain and are also the most vulnerable in a changing climate. Their engagement in this cycle of the PAR project enhanced personal awareness of climate change in their local communities and empowered them with knowledge and skills to share findings regarding the impact thereof. 
A highlight of the DOT project was the sharing of scientific and personal information with peers in another country. The collaboration of young energy from around the globe to mitigate climate change is part of a global phenomenon spearheaded by Greta Thunberg, and it is only fitting that education systems around the world enable learners to become actively involved in influencing more environmentally friendly behaviour in their communities. Not all learners can be extreme activists like Ms Thunberg, but initiatives such as the DOT project can make a difference in raising awareness and building commitment to change. The learning in this project was not confined to the classroom but was shared in the community by the learners in their role as citizen scientists. The learners were thus actively involved as producers of knowledge, which they then mobilised in their communities. We also learnt valuable lessons from this project about the need to connect teaching about climate change more closely to the impacts thereof on learners' own communities, and to train teachers to cope with any negative emotion learners may experience. The DOT strategy proved to be an effective way to make young learners aware of their responsibility towards society and the need to promote a healthy natural environment in their communities. Although social change regarding positive activities cannot be concluded by one cycle in a project, the findings of this small-scale study indicate that PAR projects incorporating participatory pedagogies such as the DOT strategy are useful, not only to reach educational outcomes but also to enable learners (and community members) to become advocates, if not activists, for climate change in their communities. And, as Greta Thunberg has warned, if adults do not recognise the urgency of addressing climate change and educating their children to act differently, they will be responsible for destroying the lives of millions of children to come.

\section{References}

Bangay, C., \& Blum, N. (2010). Education responses to climate change and quality: Two parts of the same agenda? International Journal of Educational Development, 30(4), 359-368. https://doi:10.1016/i.ijedudev.2009.11.011

Boylan, C. (2008). Exploring elementary students' understanding of energy and climate change. International Electronic Journal of Elementary Education, 1(1), 1-15. https://www.iejee.com/index.php/IEJEE/article/view/3

Brownlee, M. T. J., Powell, R. B., \& Hallo, J. C. (2013). A review of the foundational process that influences beliefs in climate change: Opportunities for environmental education research. Environmental Education Research, 19(1), 1-20. https://doi.org/10.1080/13504622.2012.683389

Brundiers, K., Wiek, A., \& Redman, C. L. (2010). Real-world learning opportunities in sustainability: From classroom into the real world. International Journal of Sustainability in Higher Education, 11(4), 308-324. https://doi:10.1108/14676371011077540

Conrad, C. C., \& Hilchey, K. G. (2011). A review of citizen science and community-based environmental monitoring: Issues and opportunities. Environmental Monitoring Assessment, 176(1), 273-291. https://doi:10.1007/s10661-010-1582-5

Corner, A., Roberts, O., Chiari, S., Völler, S., Mayrhuber, E. S., Mandl, S., \& Monson, K. (2015). How do young people engage with climate change? The role of knowledge, values, message framing, and trusted communicators. Wiley Interdisciplinary Reviews: Climate Change, 6(5), 523-534. https://doi:10.1002/wcc.353

Creswell, J. W. (2009). Research design: Qualitative, quantitative and mixed methods approaches (3rd ed.). SAGE.

Curtin, M., \& Fossey, E. (2007). Appraising the trustworthiness of qualitative studies: Guidelines for occupational therapists. Australian Occupational Therapy Journal, 54(2), 88-94. https://onlinelibrary.wiley.com/doi/abs/10.1111/i.1440-1630.2007.00661.x 
Department of Basic Education. (2011). Curriculum assessment policy statement Grades 7-9 Natural Science.

https://www.education.gov.za/Portals/0/CD/National\%20Curriculum\%20Statements\%20and\%20 Vocational/CAPS\%20SP\%20\%20AFR\%20\%20NATURAL\%20SCIENCE\%20WEB.pdf?ver=2015-01-27$\underline{160305-580}$

De Sousa, L. (2018). Citizen science investigation to promote a sustainable future and positive societal transformation [Unpublished project proposal]. North-West University, Potchefstroom].

Efstratia, D. (2014). Experiential education through project based learning. Procedia: Social and Behavioural Sciences, 152, 1256-1260.

Fals-Borda, O., \& Mora-Osejo, L. E. (2003). Context and diffusion of knowledge. Action Research, 1(1), 29-37. https://doi.org/10.1177\%2F14767503030011003

Grauer, K. (2012). A case for case study research in education. In S. R. Klein (Ed.), Participatory action research methods plain and simple (pp. 69-80). Palgrave Macmillan.

Grosseck, G., Tîru, L. G., \& Bran, R. A. (2019). Education for sustainable development: Evolution and perspectives: A bibliometric review of research, 1992-2018. Sustainability, 11(21), 6136-6171. https://doi.org/10.3390/su11216136

Grund, J., \& Brock, A. (2020). Education for sustainable development in Germany: Not just desired but also effective for transformative action. Sustainability, 12(1), 2838-2858. https://doi.org/10.3390/su12072838

Killen, R. (2010). Teaching strategies for quality teaching and learning. Juta.

King, K., McGrath, S., \& Rose, P. (2007). Beyond the basics: Educating and training out of poverty. International Journal of Educational Development, 27(4), 349-357. https://www.sciencedirect.com/journal/international-journal-of-educationaldevelopment/vol/27/issue/4

Kolb, A. Y., \& Kolb, D. A. (2005). Learning styles and learning spaces: Enhancing experiential learning in higher education. Academy of Management Learning \& Education, 4(2), 193-212. https://doi.org/10.5465/AMLE.2005.17268566

Malherbe, B. (2020). DOT challenge: Do one thing. https://braammalherbe.com/dot-do-one-thing/

McCright, A. M. (2012). Enhancing students' scientific and quantitative literacies through an inquirybased learning project on climate change. Journal of Scholarship of Teaching and Learning, 12(4), 86-102. https://files.eric.ed.gov/fulltext/EJ992129.pdf

Minkler, M. (2000). Using participatory action research to build healthy communities. Public Health Reports, 115(2), 191-197. https://pubmed.ncbi.nlm.nih.gov/10968753/

Monroe, M. C., Plate, R. R., Oxarart, A., \& Chaves, W. A. (2017). Identify effective climate change education strategies: A systematic review of research. Environmental Educational Research, 25(6), 791-812. https://doi.org/10.1080/13504622.2017.1360842

Otto, H. U., \& Ziegler, H. (2010). Capabilities-empowerment and realization opportunities in educational science. VS Verlag für Sozialwissenschaft.

Otto, S., \& Pensini, P. (2017). Nature-based environmental education of children: Environmental knowledge and connectedness to nature, together, are related to ecological behaviour. Global Environmental Change, 47(1), 88-94. https://doi:10.1016/i.gloenvcha.2017.09.009

Pace, J. L. (2019). Contained risk-taking: Preparing preservice teachers to teach controversial issues in three countries. Theory \& Research in Social Education, 47(2), 228-260. https://doi:10.1080/00933104.2019.1595240 
Santos, D. (2013). Participatory action research and the political realm. In B. Dennis (Ed.), Qualitative research: A reader in philosophy, core concepts, and practice (pp. 492-513). Peter Lang.

Schweizer, S., Davis, S., \& Thompson, J. L. (2013). Changing the conversation about climate change: A theoretical framework for place-based climate change engagement. Environmental Communication, 7(1), 42-62. https://doi:10.1080/17524032.2012.753634

Sen, A. (2010). The idea of justice. Penguin.

South African Institute for Distance Education. (2012). Getting practical: A guide to teaching and learning (3rd ed.). Oxford University Press.

Trott, C. D. (2019). Children's constructive climate change engagement: Empowering awareness, agency and action. Environmental Educational Research, 26(4), 532-554. https://doi.org/10.1080/13504622.2019.1675594

Tyler-Miller, G., \& Spoolman, S. C. (2019). Living in the environment (20th ed.). Cengage Learning.

United Nations Children's Fund (UNICEF). (2011). Exploring the impact of climate change on children in South Africa. https://www.unicef.org/southafrica

United Nations Educational, Scientific and Cultural Organisation (UNESCO). (2012a). Education sector response to climate change: Background paper with international examples. https://unesdoc.unesco.org/ark:/48223/pf0000215305

United Nations Educational, Scientific and Cultural Organisation (UNESCO). (2012b). Education sector technical notes: Climate change education education and awareness. https://unesdoc.unesco.org/ark:/48223/pf0000222117?posInSet=1\&queryld=9f765e11-46554bb3-9977-b6106de38550

United Nations Educational, Scientific and Cultural Organisation (UNESCO). (2019). SDG 4-Education 2030: Education for sustainable development beyond 2019. https://unesdoc.unesco.org/ark:/48223/pf0000366797.locale=en

Verlie, B. (2019). Bearing worlds: Learning to live with climate change. Environmental Research and Education, 25(5), 751-766. https://doi.org/10.1080/13504622.2019.1637823

Zanocco, C., Boudet, H., Nilson, R., \& Flora, J. (2019). Personal harm and support for climate change mitigation policies: Evidence from 10 US communities impacted by extreme weather. Global Environmental Change, 59(1), 1-9. https://doi.org/10.1016/i.gloenvcha.2019.101984 